Vol. 5 (1996): 17-23.

\title{
Predicting body weight from body measurements of pre-pubertal Ayrshire heifers
}

\author{
Päivi Mäntysaari \\ Agricultural Research Centre of Finland, Institute of Animal Production, FIN-31600 Jokioinen, Finland
}

\begin{abstract}
The relationship between heart girth, wither height, body length and body weight in 3- to 9.5 -monthold pre-pubertal Finnish Ayrshire heifers gaining 600-650 g/d was analysed (experiment I). Regression analysis showed that heart girth was the trait most highly correlated to body weight $\left(R^{2}=0.969\right)$. Including body length or wither height as a second term in the regression, increased $R^{2}$ values only slightly. When the relationship between heart girth and body weight was used to predict the body weight of heifers reared at two feeding levels (experiment II), the precision of prediction was affected by the plane of nutrition. Actual body weight for a given heart girth was slightly higher on the high than on the low feeding level. It is, nevertheless, concluded that the equations presented in the paper can be used to estimate accurately the body weight of pre-pubertal (95-140-cm heart girth) Ayrshire heifers gaining $550-700 \mathrm{~g} / \mathrm{d}$.
\end{abstract}

Key words: heart girth, wither height, body length, feeding level, replacement heifer

\section{Introduction}

Body weight (BW) measurements of replacement dairy heifers are important for monitoring the growth rate, optimizing nutrient allowance and determining a suitable size for breeding. Growth rate needs to be monitored, because the feeding level before puberty can affect mammary development (Sejrsen et al., 1982; Harrison et al., 1983; Niezen et al., 1992; Mäntysaari et al., 1995) and hence the subsequent milk-producing ability of heifers (Little and Kay, 1979; Foldager and Sejrsen, 1991). Since nutrient recommendations are based on BW and daily gain, it is necessary to know the live weight to optimize the nutrient intake of heifers.

Since most farmers do not have animal scales for measuring BW directly, an alternative method of estimating BW is needed. Among those used have been measurements such as heart girth, wither height, body length and hip width (Johansson and Hildeman, 1954; Kenttämies et al., 1974; Kenttämies and Vehmaan-Kreula, 1978; Verma and Hussain, 1985; Sørensen and Foldager, 1991; Heinrichs et al. 1992). In many cases, heart girth has been the trait most highly correlated to BW (Johansson and Hildeman, 1954; Nelson, et al., 1985; Heinrichs et al. 1992). However, the relationship between heart girth 
Mäntysaari, P.: Predicting body weight from body measurements

and BW may differ between breeds (Kenttämies and Vehmaan-Kreula, 1978; Sørensen and Foldager, 1991), animals of different age (Johansson and Hildeman, 1954) and animals on different feeding levels (Hvidsten, 1940; Johansson and Hildeman, 1954; Sørensen and Foldager, 1991).

In Finland, the relationship used to estimate BW from the heart girth of heifers is based on investigations by Kenttämies and VehmaanKreula (1978). In their study they excluded heifers that were younger than 6 months. However, the critical rearing period, when feeding intensity may affect mammary development, begins at 3 months of age (Sejrsen and Foldager, 1991).

The purpose of this study was to investigate the value of heart girth, wither height and body length in predicting the BW of pre-pubertal Finnish Ayrshire heifers fed restricted diets.

\section{Material and methods}

\section{Animals, diets and measurements}

\section{Experiment I}

A group of 51 Finnish Ayrshire heifers were reared to gain $650 \mathrm{~g} / \mathrm{d}$ from 3 months of age and $98 \mathrm{~kg}$ BW to 9.5 months of age and $225 \mathrm{~kg} \mathrm{BW}$. All heifers were fed the same diet, which included silage, hay, barley (when $\mathrm{BW}<200 \mathrm{~kg}$ ) and rapeseed meal (when $\mathrm{BW}<130 \mathrm{~kg}$ ). Average feed, energy and protein intakes are given in Table 1.

The body weight, heart girth, wither height and body length (from the point of the shoulders to the pinbone) of the heifers were measured every four weeks. All measurements were carried out by the same person. The total number of observations for each measurement was 408 .

\section{Experiment II}

A $2 \times 2$ factorial experiment was conducted on 24 Finnish Ayrshire heifers. The factors were two feeding levels and two protein sources. The average age and weight of the heifers at the beginning were 3 months and $87 \mathrm{~kg}$ and at the end of the experiment 9 months and $221 \mathrm{~kg}$. The average gain of the heifers on the low feeding level was $668 \mathrm{~g} / \mathrm{d}$ and on the high feeding level $848 \mathrm{~g} / \mathrm{d}$. The heifers were fed hay and barley supplemented with rapeseed meal or urea. Feed, energy and protein intakes by feeding level are given in Table 1.

During the experiment the body weight, heart girth and wither height were measured by the same person every four weeks. More detailed information about diets, feed intake, growth, slaughter weight and carcass quality of the heifers is given by Mäntysaari (1993). The mammary development of the heifers is presented by Mäntysaari et al. (1995).

\section{Statistical analysis}

The best prediction equation for BW from the body measurements was determined from the data of experiment I. After the fit of different functions had been tested, the best fit equation

$$
\mathrm{BW}=\mathrm{e}^{\Sigma \mathrm{b}_{\mathrm{i}} \mathrm{M}_{\mathrm{i}}}
$$

where $\mathrm{BW}$ is body weight, $\mathrm{M}_{\mathrm{i}}$ body measurement and $b_{i}$ the corresponding parameter, was chosen to estimate BW from body measurements. Equation 1 was transformed to a linear statistical model

$$
\ln (\mathrm{BW})=\sum \mathrm{b}_{\mathrm{i}} \mathrm{M}_{\mathrm{i}} \text {. }
$$

Regressions of the $\ln (\mathrm{BW})$ on heart girth, wither height and body length using individual observations were performed. Models were fitted using the GLM procedure of SAS (1987). Linear and quadratic effects of the independent variables were considered. The base model was:

$$
\ln (B W)_{j k}=b_{0}+b_{1} M_{j k}+b_{2} M_{j k}^{2}+S_{j}+e_{j k}
$$

where $\mathrm{BW}_{\mathrm{jk}}$ is body weight, $\mathrm{b}_{0}$ the intercept, $\mathrm{M}_{\mathrm{jk}}$ the $k^{\text {th }}$ body measurement (heart girth, wither height or body length) of the $\mathrm{j}^{\text {th }}$ heifer, $\mathrm{S}_{\mathrm{j}}$ the effect of the heifer, $b_{1}$ and $b_{2}$ are regression coefficients, and $e_{i k}$ is the residual associated with the $\mathrm{k}^{\text {th }}$ measurement of the $\mathrm{j}^{\text {th }}$ heifer.

$\ln (\mathrm{BW})$ was also regressed on multiple independent variables. Since the $\mathrm{R}^{2}$ values from the 
Vol. 5 (1996): 16-23.

Table 1. Age, body weight, growth and feed intake of the experimental heifers.

\begin{tabular}{|c|c|c|c|c|c|c|}
\hline & \multirow{2}{*}{\multicolumn{2}{|c|}{ Experiment I }} & \multicolumn{4}{|c|}{ Experiment II } \\
\hline & & & \multicolumn{2}{|c|}{ Low } & \multicolumn{2}{|c|}{ High } \\
\hline & $\mathrm{x}$ & std & $\mathrm{x}$ & std & $\mathrm{x}$ & std \\
\hline $\mathrm{N}$ & 51 & & 12 & & 12 & \\
\hline Initial age, $\mathrm{d}$ & 92 & 11.6 & 88 & 9.3 & 87 & 6.5 \\
\hline Final age, d & 288 & 11.6 & 293 & 21.1 & 249 & 20.3 \\
\hline Initial BW, kg & 98 & 12.6 & 86 & 10.7 & 87 & 10.5 \\
\hline Final BW, kg & 225 & 16.2 & 220 & 3.9 & 221 & 3.9 \\
\hline Daily gain, g & 647 & 52.6 & 668 & 45.7 & 848 & 71.3 \\
\hline \multicolumn{7}{|l|}{ Intake, $\mathrm{kg} / \mathrm{d}$} \\
\hline Dry matter & 3.59 & 0.190 & 3.73 & 0.088 & 3.91 & 0.306 \\
\hline Hay & 0.56 & 0.124 & 2.33 & 0.093 & 1.64 & 0.343 \\
\hline Silage & 2.13 & 0.178 & - & - & - & - \\
\hline Concentrate & 0.89 & 0.122 & 1.39 & 0.024 & 2.27 & 0.060 \\
\hline \multicolumn{7}{|l|}{ Nutrient } \\
\hline NE, fu/d & 3.28 & 0.157 & 2.73 & 0.055 & 3.34 & 0.150 \\
\hline $\mathrm{CP}, \mathrm{g} / \mathrm{d}$ & 479 & 14.7 & 492 & 9.0 & 561 & 28.8 \\
\hline AAT g/d & 321 & 13.7 & 327 & 14.8 & 353 & 35.6 \\
\hline
\end{tabular}

BW, body weight; NE, net energy in fattening feed units; CP, crude protein; AAT, amino acids absorbed from the small intestine (Madsen, 1985).

base regression showed that heart girth was the trait most highly correlated to $\ln (\mathrm{BW})$, heart girth was chosen as the first independent variable. A linear term for the second and third independent variables was added to the model. Thus, the models were:

$$
\ln (\mathrm{BW})_{\mathrm{jk}}=\mathrm{b}_{0}+\mathrm{b}_{1}(\mathrm{HG})_{\mathrm{jk}}+\mathrm{b}_{2}(\mathrm{HG})_{\mathrm{jk}}^{2}+\mathrm{b}_{3}(\mathrm{BL}
$$$$
\text { or } \mathrm{WH})_{j \mathrm{k}}+\mathrm{S}_{\mathrm{j}}+\mathrm{e}_{\mathrm{jk}}
$$

or:

$$
\ln (B W)_{j k}=b_{0}+b_{1}(H G)_{j k}+b_{2}(H G)_{j k}{ }^{2}+b_{3}(B L)_{j k}
$$$$
+b_{4}(W H)_{j k}+S_{j}+e_{j k}
$$

where $(\mathrm{BW})_{\mathrm{jk}}$ is body weight, $\mathrm{b}_{0}$ the intercept, $(\mathrm{HG})_{j \mathrm{jk}}$ heart girth, (BL) $)_{\mathrm{jk}}$ body length, $(\mathrm{WH})_{\mathrm{jk}}$ wither height, $\mathrm{S}_{\mathrm{j}}$ heifer, $\mathrm{b}_{1}, \mathrm{~b}_{2}, \mathrm{~b}_{3}$ and $\mathrm{b}_{4}$ are regression coefficients, and $\mathrm{e}_{\mathrm{jk}}$ is the residual.

The equation to predict BW, which was determined from the data of experiment I, was tested with the data of experiment II. The difference between predicted and actual BW was calculated and presented graphically. The goodness of fit of the equation between treatments was evaluated by testing the difference (predicted actual BW) using the MIXED procedure of SAS (1992). The model was:

$$
\mathrm{y}_{\mathrm{ijk} k}=\mu+\mathrm{F}_{\mathrm{i}}+\mathrm{P}_{\mathrm{j}}+\left(\mathrm{F}^{*} \mathrm{P}\right)_{\mathrm{ij}}+\mathrm{S}_{\mathrm{ijk}}+\mathrm{T}_{1}+\mathrm{e}_{\mathrm{ijkk}}
$$

where $y_{i j k l}$ is the prediction error, $F_{i}$ the $i^{\text {th }}$ feeding level, $P_{j}$ the $j^{\text {th }}$ protein source, $S_{i j k}$ the $k^{\text {th }}$ heifer on feeding level $\mathrm{i}$ and protein source $\mathrm{j}, \mathrm{T}_{1}$ the $\mathrm{l}^{\text {th }}$ measuring time, and $\mathrm{e}_{\mathrm{ijk} \mid}$ the residual associated with observation of the $\mathrm{k}^{\text {th }}$ heifer on the $\mathrm{i}^{\text {th }}$ feeding level and $\mathrm{j}^{\text {th }}$ protein source at time 1 .

\section{Results and discussion}

\section{Regression of body weight on different body measurements}

The increase with age in the $\mathrm{BW}$, heart girth, wither height and body length of the heifers in experiment $\mathrm{I}$ is presented in Figure 1. Correlations between $\mathrm{BW}$ and body measurements were high $(r>0.93)$. In agreement with previous studies (Johansson and Hildeman, 1954; Nelson et al., 1985; Heinrichs et al., 1992) heart girth was the trait most highly correlated to BW $(r=0.97)$. 
Mäntysaari, P.: Predicting body weight from body measurements

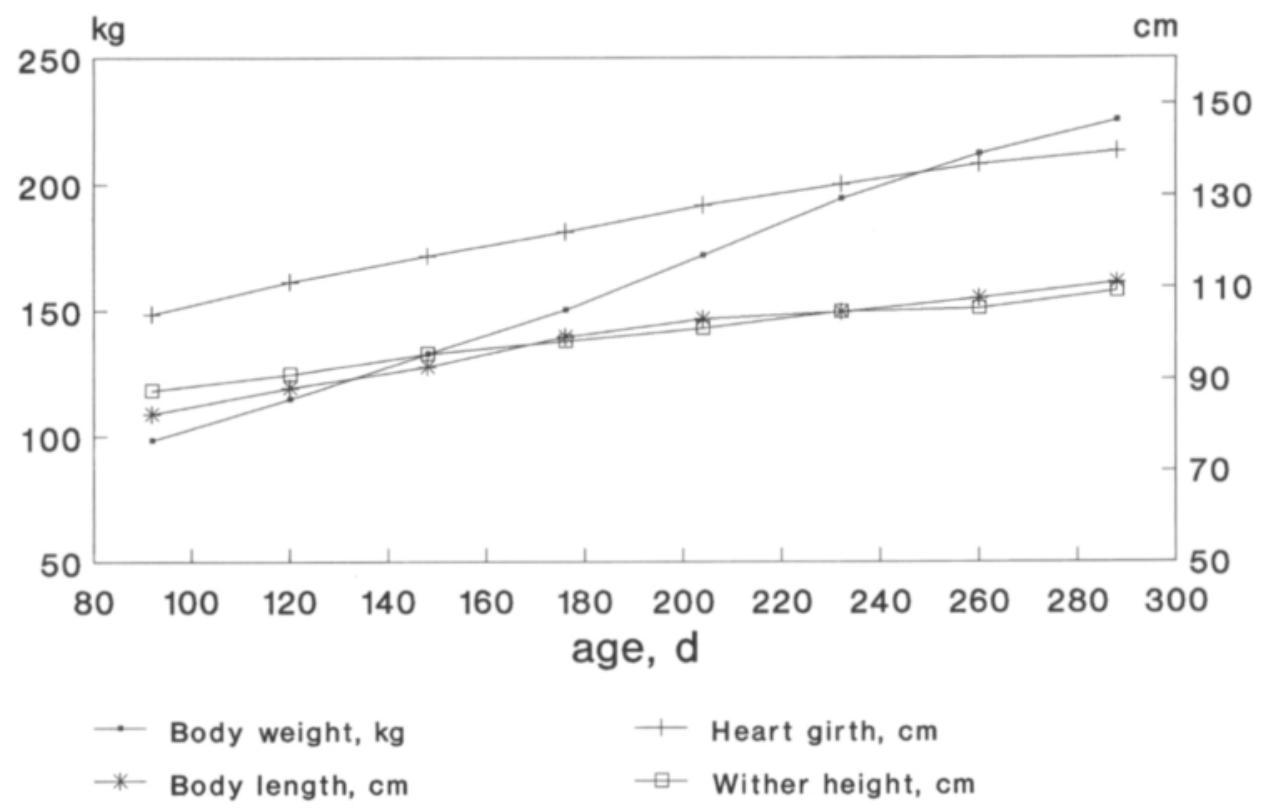

Figure 1. Development of body weight, heart girth, body length and wither height of the heifers in experiment $\mathrm{I}$.

Body weight is estimated from body measurements using the exponential function (Johansson and Hildeman, 1954; Kenttämies et al. 1974; Kenttämies and Vehmaan-Kreula, 1978, Sørensen and Foldager, 1991), although Verma and Hussain (1985) predicted the BW of calves using the linear relationship of heart girth to BW. Since the purpose of the present study was to establish the relationship of body measurements to the BW of pre-pubertal heifers, the ranges in $\mathrm{BW}$ and body measurements were relatively small. The liner regression of hearth girth, wither height or body length, therefore, estimated the BW fairly accurately $\left(R^{2}>0.914\right)$. The fit was, however, improved when equation 1 was used to predict $\mathrm{BW}$ from body measurements. The $\mathrm{R}^{2}$ values for the linear regression of heart girth, wither height and body length to $\ln (\mathrm{BW})$ were $0.967,0.929$ and 0.945 , respectively (Table 2). The additional quadratic terms were highly significant for heart girth and wither height although the increases in $\mathrm{R}^{2}$ values were small. Including them in the regression would, however, improve the prediction.

Johansson and Hildeman (1954) concluded that BW can be estimated with about the same accuracy from heart girth only as with a combination of two or several measurements. Likewise Heinrichs et al. (1992) found that an additional linear term gave only little predictive benefit. Here, too, the addition of the linear effect of body length or wither height to the regression including the linear and quadratic effects of heart girth improved the fit only slightly (Table 3 ). The inclusion of all three independent variables in the equation increased the $\mathrm{R}^{2}$ value by 0.014 .

If a higher accuracy of the BW estimation is

Table 2. Regressions of $\ln (\mathrm{BW})$ on various body measurements.

\begin{tabular}{lrlcc}
\hline Measurement Intercept & Linear & Quadratic & $\mathrm{R}^{2}$ \\
\hline Heart girth & -2.1183 & $0.02307^{\cdots *}$ & - & 0.967 \\
& 1.0453 & $0.04196 \cdots$ & $-0.00007713^{\cdots *}$ & 0.969 \\
Body length & 2.2654 & $0.02821^{\cdots *}$ & - & 0.945 \\
& 2.2512 & $0.02851^{\cdots *}$ & -0.00000154 & 0.945 \\
Wither height & 1.3685 & $0.03711^{\cdots *}$ & - & 0.929 \\
& -0.5716 & $0.07688^{\cdots *}$ & $-0.00020253^{* *}$ & 0.931 \\
\hline
\end{tabular}

$* * * \mathrm{P}<0.001$

** $\mathrm{P}<0.01$ 


\section{AGRICULTURAL AND FOOD SCIENCE IN FINLAND}

Vol. 5 (1996): 16-23.

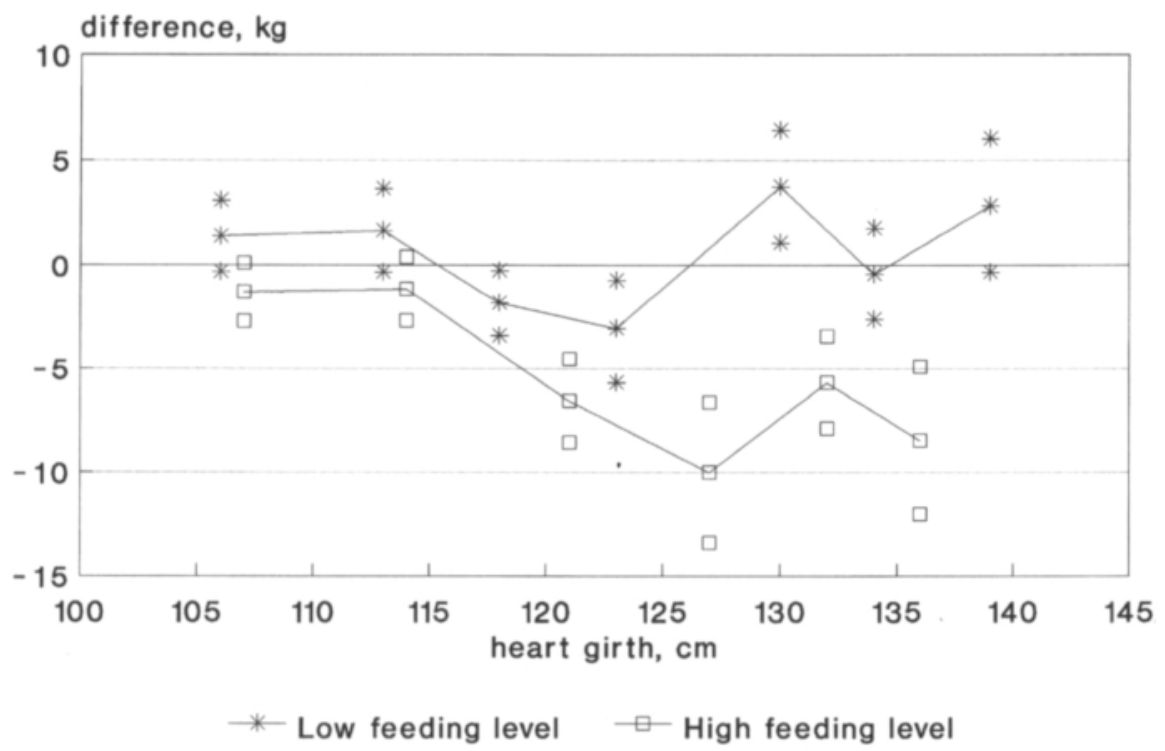

Figure 2. The mean differences ( $+/$ - corresponding standard error of the mean) between predicted and actual body weight of the heifers on high and low feeding levels in experiment II.

sought by adding another trait besides heart girth, the use of body length is more reasonable from the farmer's point of view. This is because body length can be measured with the same tape measure as heart girth; a special measuring stick is needed to obtain a reliable estimate of wither height. From a statistical point of view, however, the addition of measurements other than heart girth provides little additional information.

Table 3. Regressions of $\ln (\mathrm{BW})$ on the linear and quadratic effects of heart girth and the linear effect of body length and wither height.

\begin{tabular}{|c|c|c|c|c|}
\hline Measurement & Intercept & Linear & Quadratic & $\mathbf{R}^{2}$ \\
\hline Heart girth & 1.6908 & $0.02313^{\ldots *}$ & $-0.00003154^{* *}$ & \\
\hline Body length & & $0.00993^{* * *}$ & & 0.978 \\
\hline Heart girth & 0.9490 & $0.03138^{\ldots *}$ & $-0.00006131^{\ldots}$ & \\
\hline Wither height & & $0.01172^{\cdots *}$ & & 0.978 \\
\hline Heart girth & 1.4488 & $0.01897^{\cdots}$ & $-0.00002927^{\circ}$ & \\
\hline Body length & & $0.00767^{\cdots \cdots}$ & & \\
\hline Wither height & & $0.00936^{* *}$ & & 0.983 \\
\hline
\end{tabular}

Therefore, an equation based on the linear and quadratic effects of heart girth is recommended. The difference in predicted BW at 140-cm heart girth between the recommended equation and the table for older heifers given by Kenttämies and Vehmaan-Kreula (1978) is about $7 \mathrm{~kg}$.

\section{Effect of feeding level on the relation of heart girth to body weight}

A number of investigators have shown that feeding level can affect the relationship between BW and heart girth (Hvidsten, 1940; Johansson and Hildeman, 1954; Sørensen and Foldager, 1991;). In the present study, the usefulness of the prediction equation developed from the heifers in experiment I was evaluated for heifers on different feeding levels using the data of experiment II.

The mean differences between the estimated $\left(\mathrm{BW}=\exp \left[\mathrm{b}_{0}+\mathrm{b}_{1} \mathrm{HG}+\mathrm{b}_{2}(\mathrm{HG})^{2}\right]\right.$; see Table 2$)$ and actual $\mathrm{BW}$ of the heifers on high and low feeding levels in experiment II is presented in Figure 2. The prediction estimating the BW of 


\section{AGRICULTURAL AND FOOD SCIENCE IN FINLAND}

\section{Mäntysaari, P.: Predicting body weight from body measurements}

the heifers on the low feeding level, which had similar daily live weight gains to those in experiment I, was satisfactory, but on the high feeding level the equation tended to underestimate the BW of the heifers. In the analysis of variance, feeding level had a significant effect on the goodness of fit of the prediction model $(\mathrm{P}<$ $0.01)$. The protein source of the diet in experiment II had no effect on fit.

In agreement with our results, Hvidsten (1940) and Johansson and Hildeman (1954) found that, at a certain heart girth, an increase in the condition score increased the BW. In contrast, the plane of nutrition did not affect the relationship between the heart girth and BW of Danish Black and White heifers (Sørensen and Foldager, 1991). For Red Danish heifers, the effect of feeding level was the opposite to our results, that is, the BW at a certain heart girth was greater on lower planes of nutrition (Sørensen and Foldager, 1991).

\section{Conclusions}

The regressions showed that, from the body measurements recorded, heart girth was the trait most highly related to BW. The linear relationship of heart girth to $\ln (\mathrm{BW})$ already gave relatively accurate predictions. However, the addition of a quadratic term improved the fit. Thus, the recommended equation for predicting BW from heart girth was:

$$
\begin{aligned}
\mathrm{BW}= & \exp [1.0453+0.04196(\mathrm{HG})- \\
& \left.0.00007713(\mathrm{HG})^{2}\right] .
\end{aligned}
$$

At a heart girth of around $100 \mathrm{~cm}$, an increase of $1 \mathrm{~cm}$ increases the predicted $\mathrm{BW}$ by $2.3 \mathrm{~kg}$, whereas the corresponding increase at $130 \mathrm{~cm}$ is $4.0 \mathrm{~kg}$. This equation can be accurately used to predict the BW of pre-pubertal Finnish Ayrshire heifers whith a heart girth of 95 to $140 \mathrm{~cm}$. Since the feeding level affects the relationship between BW and heart girth, the best prediction of $\mathrm{BW}$ is achieved for heifers gaining $550-700 \mathrm{~g} / \mathrm{d}$.

\section{References}

Foldager, J. \& Sejrsen, K. 1991. Rearing intensity in dairy heifers and the effect on subsequent milk production. National Institute of Animal Science, Foulum, Denmark. Report 693, 131 p.

Harrison, R.D., Reynolds, I.P. \& Little, W. 1983. A quantitative analysis of mammary glands of dairy heifers reared at different rates of live weight gain. Journal of Dairy Research 50: 405-412.

Heinrichs, A.J., Rogers, G.W. \& Cooper, J.B. 1992. Predicting body weight and wither height in Holstein heifers using body measurements. Journal of Dairy Science 75: 3576-3581.

Hvidsten, H. 1940. Calculations of the weight of cattle by measuring. 49th Report of the Institute of Animal Nutrition. The Royal Agricultural College of Norway. 39 p.

Johansson, I. \& Hildeman, S.E. 1954. The relationship between certain body measurements and live and slaughter weight in cattle. Animal Breeding Abstracts 22: 1-17. Kenttämies, H., Taivalantti, P. \& Vehmaan-Kreula, E. 1974. Lehmien elopainon määrittăminen rinnanympăryksen avulla. Kehittyvă Maatalous 18: 3-15.

- \& Vehmaan-Kreula, E. 1978. Hiehojen rinnanympäryksen mittaamisesta hyötyä. Nautakarja 1/78: 15-16. Little, W. \& Kay, R.M. 1979. The effects of rapid rearing and early calving on the subsequent performance of dairy heifers. Animal Production 29: 131-142.
Madsen, J. 1985. The basis for the proposed Nordic protein evaluation system for ruminants. The AAT-PBV system. Acta Agriculturae Scandinavica, Supplement 25: 920.

Mäntysaari, P. 1993. The effects of feeding level and protein source of the diet on growth and development at slaughter of pre-pubertal heifers. Acta Agriculturae Scandinavica, Section A, Animal Science 43: 44-51. -, Ingvartsen, K.L., Toivonen, V. \& Sejrsen, K. 1995. The effects of feeding level and nitrogen source of the diet on mammary development and plasma hormone concentrations of pre-pubertal heifers. Acta Agriculturae Scandinavica, Section A, Animal Science 45: 236-244. Nelson, T.C., Short, R.E., Reynolds, W.L. \& Urick, J.J. 1985. Palpated and visually assigned condition scores compared with weight, height and heart girth in Hereford and crossbred cows. Journal of Animal Science 60: 363368.

Niezen, J.H., Grieve, D.G., McBride, B.W. \& Burton, J.H. 1992. Effect of plane of nutrition in two periods on growth and mammary gland development in pre-pubertal Holstein heifers. Journal of Dairy Science 75, Supplement 1: 271.

SAS 1987. SAS/STAT ${ }^{\mathrm{TM}}$ Guide for Personal Computers. Version 6 Edition. SAS Institute, Cary, NC. 1028 p.

- 1992. SAS' Technical Report, P-229. SAS/STAT Soft- 
Vol. 5 (1996): 16-23.

ware: Changes and Enhancements. SAS Institute., Cary, NC. $620 \mathrm{p}$.

Sejrsen, K., Huber, J.T. Tucker, H.A. \& Akers, R.M. 1982. Influence of nutrition on mammary development in pre- and postpubertal heifers. Journal of Dairy Science 65: 793-800.

Sorensen, J.T. \& Foldager J. 1991. Effect of breed and plane of nutrition on the estimation of live weight by heart girth in dual purpose heifers. Acta Agriculturae Scandinavica 41: 161-169.

Verma, D.N. \& Hussain, K.Q. 1985. The estimation of the body measurement of calves from heart girth measurements. The Indian Veterinary Medical Journal 9: 112114.

\title{
SELOSTUS
}

\section{Hiehojen elopainon määrittäminen mittauksin alkukasvatusvaiheessa}

\author{
Päivi Mäntysaari \\ Maatalouden tutkimuskeskus
}

Tutkimuksen tavoitteena oli selvittää mittausten käyttökelpoisuutta 3-10 kuukauden ikäisten hiehojen elopainon määrittämisessä. Elopainon kehityksen seuraaminen jo alkukasvatuskaudella on välttämätöntä, sillä utareen kehityksen kannalta kriittinen kasvunvaihe alkaa noin 3 kk iässä. Kokeessa mitattiin elopaino, rinnanympärys, pituus ja säkäkorkeus $3-9,5 \mathrm{kk}$ ikäisiltä hiehoilta, joiden keskimääräinen päiväkasvu oli $650 \mathrm{~g}$. Mittojen ja elopainon välisiä yhteyksiä pyrittiin selvittämään regressioanalyysillä. Rinnanympäryksen perusteella pystyttiin parhaiten ennustamaan elopainoa $\left(\mathrm{R}^{2}=0,969\right)$. Kun rinnanympäryksen lisäksi regressiomalliin lisättiin sekä pituus että säkäkorkeus, lisääntyi ennusteen varmuus vain vähän $\left(R^{2}=0,983\right)$. Hiehojen elopainoa suositeltiin arvioitavan rinnanympäryksen perusteella kaavalla
$\mathrm{EP}=\exp \left[1,0453+0,04196(\mathrm{RY})-0,00007713(\mathrm{RY})^{2}\right]$, missä EP = elopaino ja RY = rinnanympärys. Yhtälöä voidaan käyttää, kun rinnanympärys on $95-140 \mathrm{~cm}$. Yhtälöä testattiin toisella hiehoaineistolla. Testiaineiston hiehoja oli kasvatettu kahdella ruokintatasolla. Alhaisella tasolla hiehojen kasvu oli $668 \mathrm{~g} / \mathrm{d}$ ja korkealla $848 \mathrm{~g} / \mathrm{d}$. Elopainon ja rinnanympäryksen välisen yhteyden todettiin olevan riippuvainen ruokinnan voimakkuudesta. Malli ennusti alhaisen ryhmän hiehojen elopainon suhteellisen luotettavasti, mutta aliarvioi voimakkaasti ruokittujen hiehojen elopainon. Koska esitetty elopainon arvioimisyhtälö perustuu rajoitetusti ruokittujen hiehojen mittauksiin, antaa se parhaan ennusteen hiehoille, joiden päiväkasvut ovat $550-700 \mathrm{~g}$. 